\title{
Where Are the Chinese Cities Heading?
}

Three Approaches to the Metropolis in Contemporary China

Jean-François Doulet

\section{(2) OpenEdition}

\section{Journals}

Electronic version

URL: http://journals.openedition.org/chinaperspectives/4729

DOI: $10.4000 /$ chinaperspectives. 4729

ISSN: 1996-4617

\section{Publisher}

Centre d'étude français sur la Chine contemporaine

\section{Printed version}

Date of publication: 1 December 2008

Number of pages: 4-14

ISSN: 2070-3449

Electronic reference

Jean-François Doulet, "Where Are the Chinese Cities Heading? », China Perspectives [Online], 2008/4 | 2008, Online since 01 December 2011, connection on 28 October 2019. URL : http://

journals.openedition.org/chinaperspectives/4729; DOI : 10.4000/chinaperspectives.4729

(C) All rights reserved 
(T)

\section{Where are China's Cities}

\section{Heading?}

Three approaches to the metropolis in contemporary China

JEAN-FRANÇOIS DOULET

Metropolisation is essential to approaching the current changes in urban China. We put forward three complementary approaches to understanding the main phenomena that structure the Chinese metropolis today and will mould it tomorrow: hypermodernity, contestation, and regulation.

$\mathrm{A}$ $s$ it approaches the symbolic urban population threshold of 50 percent, ${ }^{(1)}$ today's China is being structured to a large extent by a formidable process of urbanisation that particularly favours the metropolises, those cities of millions that benefit from both a sizeable population and a powerful capacity to concentrate wealth and command functions. In these spaces, the reforms undertaken by the Chinese government over the last 30 years are constantly remodelling economic, political, and social structures in an atmosphere of excitement that consistently arouses interest worldwide. This interest can be explained as much by the extent of the changes as by the increasing similarity of the processes underway to universal problematics.

This growing interest in the evolution of Chinese cities reinforces the idea that today's China has become "the latest frontier of urban studies," in the words of the Canadian academic John Friedmann. ${ }^{(2)}$ This idea of the frontier attracts attention in two ways: on the one hand, Chinese cities provide an exceptional terrain of observation for those interested in cities and their development, and on the other, they appear to many observers as spaces with high innovation potential. How can the changes underway be understood? What are the main forces driving change? What is being invented in Chinese cities? In response to these questions, this article offers a means of understanding metropolisation through an analysis of urban studies on China.

\section{The hypothesis of the normali- sation of Chinese urbanisation}

The hypothesis of the normalisation of Chinese urbanisation is based on the idea that China's urbanisation process seems to be following a path similar to that of other countries, accompanied by the belief that an improved understanding of urban phenomena is made possible by the increase in research on the subject. In other words, Chinese urbanisation is becoming normal in the sense that there is a similarity between what is happening in China and what is happening elsewhere, and in the sense that increasing knowledge tends to diminish the "exoticism" that surrounds Chinese cities, a conclusion reached by the political scientist and sinologist Jean-Luc Domenach in a book whose title, Où va la Chine? (Where is China heading?), ${ }^{(3)}$ we have used for this article.

\section{The enrichment of urban studies on China}

Urban phenomena in China are better known today, so great is the range of disciplinary approaches and of attempts to draw out a common field of thought that combines studies produced in the West with studies produced in China. ${ }^{(4)}$ It is particularly worth noting the predominance of the literature in English in the field of urban studies on contemporary China, ${ }^{(5)}$ as well as the increasing translation of Chinese texts on the subject. ${ }^{(6)}$ Research into Chinese cities is leading to new configurations in which many specialists on

1. Around $45 \%$ in 2007 , according to the National Statistics Bureau.

2. John Friedmann, "China's Urbanization," International Journal of Urban and Regional Research, vol. 273, 2003, pp. 745-758.

3. It is interesting to reread the introduction to this book, published by Fayard, which puts into perspective studies on contemporary China in the way they influence the observation and understanding of contemporary China.

4. Specialists in urban studies in China contribute considerably to this overall coherence, in particular the English geographer Wu Fulong.

5. This is also true of many of the studies on contemporary China.

6. One should note in particular the parallel initiatives carried out in France by Laurence Roulleau-Berger (Laurence Roulleau-Berger et al. (ed.), La nouvelle sociologie chinoise Paris, Editions du CNRS, 2008), and Jean-Louis Rocca (Jean-Louis Rocca (ed.), La société chinoise par ses sociologues, Paris, Presses de Sciences Po, 2008), to make known the work of certain Chinese sociologists, some of whom focus on the city. 
China come to the cities, many urban specialists come to China, and specialists on the city are including urban China in their analyses. In any case, a more accessible terrain brings capitalisation of knowledge and know-how from several disciplines, ranging from the American sociological and geographical analyses of the 1980s to the more recent Chinese analyses on sociology and other urban fields. A crossfertilisation of discourse and a mutual enrichment result in a normalisation of the subject that makes it more easily approachable.

\section{seeking to comprehend the "post-Maoist city"}

The enrichment of knowledge in urban studies makes it easier to put into perspective the processes underway in today's China, a China that has been drastically changed by the reforms the Chinese regime launched at the end of the 1970s. The expression "post-Maoist city" comes from the Englishlanguage literature; it necessitates putting into perspective contemporary phenomena in contrast with the "Maoist" city. The Maoist city is easily caricatured by political choices that were clearly antagonistic to the city, to the point of a perceived "anti-urban" policy on Mao's part. ${ }^{(7)}$ In the early 1980s, the first urban studies on China largely contributed to underlining the forms of control over urban growth established by the Maoist regime for essentially political reasons. It emerged that Maoism managed to limit the growth of cities from a demographic point of view, thanks to migration control through the $h u k o u^{(8)}$ system, and from an organisational point of view by remodelling the socioeconomic organisation of the cities around production structures, the work units (danwel); and control units, the neighbourhood committees (jumin weiyuanhul). ${ }^{(9)}$ Mao is said to have curbed urban growth, making China an exception among other developing countries, which during the same period of the 1960s and 70s were in the throes of what has been termed "urban embolism," the uncontrolled development of megalopolises. ${ }^{(10)}$ Once sociological, urban, historical, and political analyses had laid down certain markers for understanding the influence of Maoism on the city, urban studies on China flourished on the basis of the "Maoist city," which at the time was easier to comprehend. It is this methodological parti pris of an abrupt break that gave meaning to the urban transformation in China under the reforms. This break is less obvious in Chinese literature on the cities, which tends to employ the perspective of a continuous process since 1949. ${ }^{(11)}$

\section{The access point of metropolisation}

The processes at work in the context of the reforms may be bringing the urban problematics in China closer to corresponding problematics in other parts of the world. The "postMaoist city" in particular is thought to be moulded by the process of metropolisation that appears in the field of urban studies as the latest metamorphosis in the development of cities, characterised by the increasing weight of the urban population and by the perceptible increase in the influence of the cities on society and on the country as a whole. This phenomenon of metropolisation is rooted in globalisation, which has a considerable influence on exogenous modalities of urbanisation and explains, among other things, the attention given to the impact of foreign investment in China's urban growth. In the Chinese case, the reforms imposed on the cities from 1984 onwards were thought to have the effect of bringing Chinese urbanisation closer to regularities identified elsewhere.

"Post-Maoist" China is indeed one of the areas in the world most affected by urban growth. Since the country initiated its reforms at the end of the 1970s and at the beginning of the 1980s, urbanisation has become one of the concomitant elements in its economic and industrial development. The level of urbanisation in China at the end of the 1970s was only 20 percent, according to United Nations estimates, whereas it is now close to 50 percent. With an annual average growth rate of over 3 percent since the beginning of the 1990s, China is experiencing a genuine urban revolution: every year the urban population increases by 30 million. This phenomenon is particularly based on the increasing size of the major cities, especially the very big cities: there are now more than 40 cities with populations exceeding two million. ${ }^{(1)}$ Recent projections predict that China will have 221 cities with populations of more than one million in 2025. ${ }^{(13)}$ While all the urban studies on China begin by not-

7. This article deliberately does not seek to underpin the historical analyses of twentieth century urban China in order to concentrate selectively on modes of interpretation and the highlighting of the reform period.

8. The hukou system was established in the 1950 s and is still in operation today, although its constraining aspect has been partially lifted.

9. Mention should made of the standard and broadly pioneering work by the American sociologists Martin Whyte and William Parish, Urban Life in Contemporary China, published in 1984 by the Chicago University Press.

10. It is interesting to note the surprise felt by some urban specialists from Europe on their first visits to certain major Chinese cities, which looked more like villages than cities.

11. We should note however, that this distinction is gradually being made.

12. According to the 2007 Chinese Cities Statistical Yearbook.

13. In comparison, Europe now has 35 cities of this size (McKinsey Global Institute, Preparing for China's Urban Billion, McKinsey \& Co, 2008). 
Model of the new Beijing's CBD (c) J-F. Doulet

ing that metropolisation constitutes a new framework, points of view differ on the dominant forces and their long-term impact on the description of the Chinese city. There are several possible approaches, which remain largely complementary.

\section{Towards the hypermodern metropolis}

Some analyses of today's urban China emphasise the break from Maoism and the influence of the new forces produced by the reforms; their impact is most noticeable in the reduced participation of the state in the modelling of urban development. The transition underway is thought to reflect the natural transition to a context of increased freedom for market forces and individual emancipation. The phenomena emerging with metropolisation in the context of the reforms are thus thought to contribute to China's integration into a new modernity, and the city that emerges is considered closer to the image of the hypermodern city, that of advanced modernity put forward by some European urban specialists. ${ }^{(14)}$ This approach, tinged by free enterprise, is in general agreement with the Chinese institutional perspective, which holds the progress of the reforms to be essential for the modernisation of the country. Behind this approach is the idea that the changes underway position Chinese cities on a linear trajectory that combines progress with improvement. A recent study by the World Bank thus praises the virtues of Chinese urban development, which has managed to find the investment necessary to guarantee mass access to urban services. ${ }^{(15)}$

Some studies seek to show on the one hand how Chinese cities ensure their competitiveness and on the other how individuals elaborate their own strategies in a break from the collective structures imposed by Maoism. "Post-Maoist" China is shaking off the shackles inherited from Maoism: Chinese cities, now better equipped, are becoming more competitive in global networks; individuals, freed from the yoke of socio-political control mechanisms, are seen as fullyfledged participants in their personal development and in the development of the cities.

\section{The competitiveness of the cities}

The competitiveness of Chinese cities is ensured by better access to international capital and better connections to global networks. The 1984 reforms in urban economics and decentralisation, and especially those of 1992 in land own-

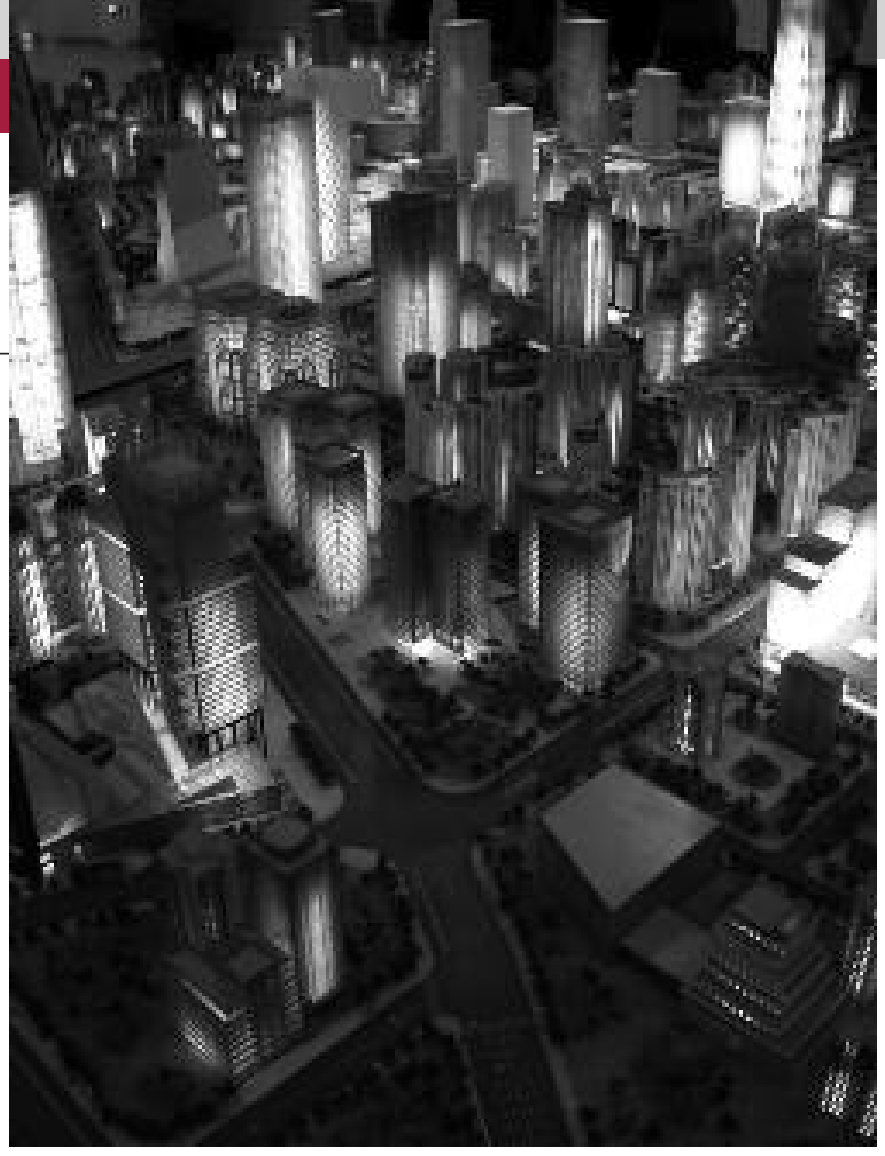

ership, have made possible the establishment of more autonomous urban development mechanisms. Over time Chinese cities have concentrated certain functions, including finance, with the opening of the Shanghai and Shenzhen stock markets, and the organisation of international events such as the Beijing Olympics in 2008. Following the urban reforms of 1984, the major cities have carried economic growth, tending to attract not only internal migration flows, but also investment. This is the revenge of the metropolises on the Mao years, which had been characterised by disinvestment of urban services. As in other parts of the world, we are witnessing a metropolisation of economic activity in China: the metropolises are concentrating investment as well as economic players (corporate headquarters, stock markets, transport hubs, etc.).

The concentration of wealth in the metropolises initially corresponded to the universal migration of economic activity to the coastal areas at a time when China, in the early 1980s, was opening up to the world with the establishment of the first Special Economic Zones (SEZs). In contrast with Maoist policy, which favoured the inland cities, Deng's regime based itself on the urban legacy of the great coastal port cities to sustain a policy of growth. The strategy of taxfree zones widely served to open the eastern cities to foreign investors, initially from Taiwan and Hong Kong. From 1992 on, the instrument of the tax-free zone was extended to a large part of the network of big cities through the economic

14. In France the work of François Ascher has contributed to the understanding of the hypermodern city.

15. China Urbanizes: Consequences, Strategies and Policies, East Asia's Economic Prospects, Washington, The World Bank, 2008. 
and technology development zones (ETDZ). Up to now, it has been the eastern metropolises that have produced and concentrated most of the wealth in a dynamic of consolidation: these metropolises not only benefit from major public investment, massive flows of foreign direct investment (FDI), and a high concentration of industrial and commercial activity, but they have also seen the emergence in the last ten years of services with high added value, such as those relating to finance and research and development $(R \& D)$. However, a noticeable trend is changing the picture: rising rents and labour costs in the eastern cities are making the major inland cities more attractive for certain activities. $^{(16)}$

The new Chinese urban network highlights a constantly increasing number of metropolises, some of which rank high on international listings of global cities that influence world business. Like other international metropolises of the same rank, they live by the rhythms of international trade and information and communication networks. Chinese metropolises are emerging from the shadows. The Shanghai stock market, despite the criticisms still levelled at the accounts of some major listed Chinese companies, has become an essential financial marketplace, mainly for investors who want to avail themselves of high profitability. The Chinese metropolises continue to attract local offices of major international companies, whose expansion in China is often proportionate to the number of consumers in the Chinese domestic market. Another criterion is the increasing importance given to services with high added value and to new technologies, since the Chinese metropolises concentrate a highly-trained labour force, advanced know-how, and technological facilities. Several multinationals have decided to open $R \& D$ centres in China, recent examples being Microsoft in Beijing, and PSA Peugeot-Citroën in Shanghai.

\section{Individualisation and the marketing of urban space}

In the more competitive metropolises that are more open to the world, urban space becomes a marketable commodity and the site increasingly diverse economic transactions and new consumer practices. Individuals seem freer and more inclined to develop their own strategies on the basis of a new social contract and a new allocation of resources ${ }^{(17)}$ : the decline of Maoist control structures produces complex strategies linked to professional and residential mobility. Also, individuals may distinguish themselves according to their ability to choose the best solutions in a given situation. For ur- banites in the Maoist era, the danwei was an essential reference point: it allowed access not only to employment but also to housing, everyday services, and leisure activities. A "total social entity," ${ }^{(18)}$ the work unit situated the individual in the space of social and spatial proximity. The reform of state enterprises gradually eliminated the work units under the influence of the "socialisation" (shehuihua) movement, which enjoined enterprises to abandon the management of access to certain services, such as housing, in order to concentrate on their core activities. Individuals had to gradually learn autonomy in order to acquire what the French sociologist Alain Bourdin refers to as "metropolitan competences." ${ }^{(19)}$ Some see the emergence of a consumer society as structuring urban society in China today. ${ }^{(20)}$ It is because money makes urban space available that individuals and social groups have begun to emerge.

The strategies of individuals, couples, and collectives mould social dynamics in cities today. Some studies have focused particularly on the role played by housing in these strategies. The housing reform of 1992, which facilitated ownership, incited Chinese urbanites to invest in their residence, revealing new strategies of residential mobility in which there appeared, over and above the consideration of price, rational choices such as a good school for one's child, and less rational ones, such as the image of a particular neighbourhood. The relationship to housing is now shaped by more individualistic forms, far removed from the friendly environment of "traditional" residential neighbourhoods constituted by social and spatial proximity. ${ }^{(21)}$ The result is that lifestyle is organised less and less around the danwei, as in the Maoist city, and more and more around the residence, which has become a real base in "postMaoist" urban China. This new base is accompanied by a

16. In 2008 , with the reduction in world demand and the increase in salaries on the east coast, many enterprises that specialise in the production of consumer goods such as toys and shoes had to close down, especially in Guandong Province, with some relocating to the interior.

17. Tang Wenfang and William L. Parish, Chinese Urban Life Under Reform: The Changing Social Contract, Cambridge, Cambridge University Press, 2000.

18. To use the formulation of the French economist Corinne Eyraud (Corinne Eyraud, L'entreprise d'Etat chinoise: De "I'institution sociale totale" vers l'entité économique, Paris, L'Harmattan, 1999).

19. See his La métropole des individus, Editions de l'Aube, 2005.

20. English language studies on China give much attention to access by merchandising of urban space, in particular those edited by American sociologist Deborah Davis. See Deborah S. Davis et al. (ed.), Urban Spaces in Contemporary China, Cambridge, Cambridge University Press, 1995, and Deborah S. Davis (ed.), The Consumer Revolution in Urban China, Berkeley, University of California Press, 2000.

21. In China, reference to the traditional residential neighbourhoods is increasingly used as an argument to denounce today's individualism. 
greater fragmentation of everyday activity in urban space, whether shopping or meeting one's friends. Access to mobile equipment, from the automobile to the mobile phone, also contributes to the expansion of better organised social and spatial practices. ${ }^{(22)}$

\section{Perspectives on the cultural and creative potential of the cities}

Approaches to the hypermodern metropolis under construction give glimpses of the image of a city that, while incomplete, give highly promising perspectives for development. Particularly noteworthy among the studies currently underway are those that concentrate on the creative and innovative industries in the city. The major Chinese cities are increasingly connected to the wider world and to modernity: economic and social change is pushing them to adopt the themes of creation and innovation. Art, multimedia, advertising, cinema, design, and new technologies help produce new aesthetic, cultural, artistic, and even scientific and technological references. At the heart of this are the Chinese "creative classes" (23) who set off new dynamics in cities that previously emphasised their comparative advantage in terms of production activities with low added value based on low labour costs.

Some analyses seek to understand how these "creative classes" absorb diverse influences from all over the world, how they appropriate urban space, and how they produce new influential places. Some of the places of Chinese creative and artistic production are already well known, such as the 798 factory in the northeast suburbs of Beijing, also known as Dashanzi, or the Moganshanlu space on the edge of the Suzhou River in the centre of Shanghai. Former factories and warehouses, these sites were initially occupied in an unofficial fashion before establishing themselves as sites for artistic production and the art market. Seeking to satisfy a demand for culture on the part of an increasingly wealthy portion of the population who want to benefit from activities linked to innovation and creation, the Chinese authorities are trying to change the label "Made in China" to that of "Created in China." ${ }^{(24)}$ They therefore support the opening of creative industry parks where artists, start-ups, and art galleries can come together.

The hypermodern city approach offers futures based on the idea that China is in the process of becoming an economic power in the world of tomorrow and that its cities will be able to establish themselves as sources of new cultural influences and as sites of innovation production.

\section{Towards the contested metropolis}

The reforms implemented in Chinese cities change the balance of power and contribute to the creation of major inequalities. Some studies emphasise conflicts of interest between social groups in Chinese cities today. This approach is based on the forms of protest that profoundly shape the social and political space in urban China. It is an approach that refutes the idea of transition based on the image of a linear development of Chinese cities, suggesting instead a mechanism of permanent tensions around which the balance of power oscillates. In this approach, Chinese urbanisation is perceived in an economic dimension as the product of a new organisation of capital and production linked to ongoing industrialisation. To some extent, the new wage relations account for the dominance of the new possessors of capital over the new urban proletariat. The living and working conditions of large numbers of people in the urban areas of the east coast go hand-in-hand with a high degree of insecurity. In particular, studies of the progress of migrant workers from the countryside (mingong) confirm that the ongoing urbanisation and industrialisation in eastern China depend to a large extent on the availability of an enormous pool of labour in the country's rural heartland. A number of studies seek to identify the social problematics that appear in today's urban China, and raise the question of how to deal with them.

\section{Social exclusion and urban poverty}

Some researchers and analysts focus on how reforms have led to the exclusion and even the marginalisation of certain social groups. ${ }^{(25)}$ On the one hand are the urban workers whose living conditions have deteriorated because of restructuring in certain industrial sectors. The reform of state enterprises in 1988 produced wholesale layoffs of workers in unproductive factories that were a legacy of mass industrialisation under Maoism. It is not surprising that the main centres

22. Some work focuses on the way in which ICTs influence the daily behaviour of Chinese urbanites. See Shang Dan, Jean-François Doulet, and Micheal Keane, "Urban Informatics in China," in Marcus Foth (ed.), Handbook of Research on Urban Informatics, Hershey and New York, IGl Global, 2008, pp. 379-389.

23. To use the widely adopted expression of American Richard Florida.

24. Michael Keane, Created in China: The Great New Leap Forward, London, Routledge, 2007.

25. See French sociologist and sinologist Jean-Louis Rocca's instructive La condition chinoise, published by Karthala in 2006.

26. On this question see Swiss political studies analyst Antoine Kernen's La Chine vers l'économie de marché: Les privatisations à Shenyang, Paris, Karthala, 2004 
of heavy industry were the first to be hit, like the city of Shenyang in the northeast. ${ }^{(26)}$ Excluded groups in the cities also increasingly include mingong. A number of studies seek to understand how the "new" urbanites establish themselves in the cities under what are often precarious conditions. Chinese sociologists analyse the impact of the transfer of masses of peasants to cities where the socioeconomic structures are profoundly different from those in the countryside; the debate revolves around the ability of the cities to absorb these rural populations. ${ }^{(27)}$ Even now, the driving force of urban growth is made up of internal migration: every year tens of millions of new urbanites come to settle in the cities. The problem accelerated in 1994, when the Chinese regime loosened the control previously imposed over migration through the hukou, a document imposed by Mao at the end of the 1950s.

While the reality of the phenomenon of rural exodus in China is debated and refuted by some who study migration from the country to the cities, ${ }^{(28)}$ it is nevertheless true that the cities have benefited greatly from this supply of labour. One of the subtleties in calculating the contribution of migration to urban growth is essentially statistical: there is on the one hand a real migration contribution linked to geographical mobility, and on the other the contribution of the rural population brought about by the expansion of the urban perimeter. Thus a series of decisions taken in the 1980s and 90s to increase the administrative perimeters of the cities in anticipation of planning efforts resulted in the absorption of entire villages without their way of life being affected at first. While it is still difficult to evaluate the balance of migration to the cities because of a number of statistical biases, in particular the informal character of much migration, it seems clear that it is the main contribution to urban growth today. Most Chinese metropolises are home to several million people who make up what is commonly referred to as the "floating population" (liudong renkou). ${ }^{(29)}$

Whether they are mechanically incorporated into the administrative areas of the cities or actively migrate to the cities by choice, these neo-urbanites often find it difficult to settle in. In most cities, employment policies have favoured the hiring of peasants whose land had been taken over by urbanisation: a peasant would be given employment as a caretaker or cleaner in the new building erected on his land. Nowadays, the massive influx of peasants since the loosening of controls over migration complicates economic integration measures and reduces the effectiveness of the full employment policies that post-Maoist China had successfully established to manage the transition. Thus many of the peasants who move to the cities today often find themselves in an unstable situation, although many success stories are told. Linked to the analyses of the difficult integration of the mingong in the cities, recent studies show an increase in extreme poverty, which has often become strikingly obvious.

\section{Socio-spacial segregation}

Chinese metropolises today are experiencing strong social and spatial diversity, which was not so obvious under the controlled development of the egalitarian Maoist city. While the building of a middle class through new consumer habits and strategies is evident, one remains struck by the dual character of urban society, mainly on its extremities. This duality rests on obvious forms of socio-spatial segregation: on the one hand, migrant workers who have great difficulty finding housing in the slum-like "urban villages" on the relatively far-flung peripheries of the main metropolises, and on the other, the gated communities of the wealthy, based on European or American models. It is striking to observe how social segregation and the wider effects of China's openly recognised social stratification ${ }^{(30)}$ are made visible in urban space.

Studies have been carried out since the early 1990s on the unofficial neighbourhoods of migrants, in particular Zhejiangcun in Beijing, which has attracted considerable attention. These spontaneous neighbourhoods resemble in many respects the shantytowns or favellas of metropolises in other developing countries. Bringing together people from the same province, they operate as entry points for those recently arrived in town, who can depend on mutual help networks, mainly in order to find employment and housing. These areas have often triggered public condemnation and provoked strong reactions from the authorities, who have sometimes sought to demolish them as breeding grounds of increasing crime.

In parallel with the emergence of these urban slums, a number of closed residences have appeared, based on the model of the gated communities of American, Brazilian, and

27. See in particular the work of Chinese sociologist Cheng Yinfang of Shanghai's Huadong University.

28. See the work on Chinese migrants by the French sociologist and sinologist Isabelle Thireau.

29. Around 3 million in Beijing and in Shanghai, and considerably more in Shenzhen, where the workshops and factories of the big multinationals attract droves of workers.

30. Essentially since the Chinese Academy of Social Sciences produced two complementary reports early in the decade on social stratification and the modalities of social mobility in today's China. 
French metropolises. These residences, which are built on the edges of cities and even in the centre, as in Guangdong, remain closed in on themselves, clearly demarcated by boundary walls or railings, and even have video surveillance systems or guards. Built according to architectural references borrowed from international and mainly American models, they are highly prized by the urban elites. ${ }^{(3)}$ While falling short of the excesses of overseas gated communities, many of the new residential neighbourhoods (xiaoqu) of today's urban China satisfy a demand for security; they also depend on the quest for a comfortable space based on a particular concept of the neighbourhood, which to some extent recalls the neighbourhood committees in Maoist China. Some might explain that access to home ownership in today's urban China is in the process of constructing the figure of the bourgeois property owner, an emblematic figure in nineteenth century Europe, who became a power of resistance in his effort to defend his rights. There have been innumerable complaints by residents over factories spoiling the environment of their neighbourhood or problems caused by public development projects. ${ }^{(32)}$

\section{Perspectives on the development of forms of urban protest}

Approaches to the contested metropolis show a city whose project, based on the free market, seems to be split and in any case widely called into question. Numerous analyses today examine the emergence of the Chinese city as a contested space, mostly by those who feel excluded or cheated, and those who feel that the decisions being taken are not legitimate or that they are contrary to the general interest. Forms of urban protest have been essentially analysed through the demonstrations organised by workers on industrial sites who were redeployed or laid off in the 1980s as part of the restructuring of major state enterprises. Street demonstrations had thousands of workers marching to demand better social and economic provisions. This contestation seemed to be the reaction to reforms that disrupted well-established urban rhythms, those of the Maoist city organised around the danwei, which assured the stability of urban organisation. These forms of protest were echoed in the countryside, where peasants complained of declining incomes and reduced buying power as a result of excessive taxation.

Another direction for the analysis of urban contestation also opened up with public reactions to urban renewal projects, which linked the issue of forced expulsions of residents to the preservation of urban heritage. The centres of the great Chinese metropolises are under heavy development pres- sure, especially since the reform of 1992, which saw the emergence of property developers. Land in the centre is more expensive and thus more attractive to those who seek to maximise profits from urban development, which very often consists of forcibly expelling the residents of a neighbourhood and then demolishing it entirely. At the heart of the historic cities, the demolished neighbourhoods have a high heritage value. This story has been endlessly repeated in Shanghai, Beijing, Chengdu, and finally almost everywhere else, producing increasingly regular protests from expelled residents as well as from many intellectuals, architects, and academics who support heritage preservation. ${ }^{(33)}$ The law on private property passed in March 2007 opens new perspectives for the possibility of urbanites protecting their housing rights in the context of these demolitions.

The perspectives laid out by the contested metropolis approach call for a potential shift in the balance of power and thus to more or less violent conflicts in the case of a steadily growing wealth and income gap, ${ }^{(34)}$ all the more so as the means of expression and protest, such as the Internet, ${ }^{35}$ continue to increase. This approach urgently raises the question of the "right to the city," in the words of the French sociologist Henri Lefebvre. Thinking is being focused on urban policies, or what in the French context is known as "city policy," in particular the question of public housing and a wider establishment of social security mechanisms. While some think the various forms of urban contestation could lead to political instability, ${ }^{(36)}$ one can believe that what is at stake is the ability of the authorities to respond to demands for better distribution of wealth and better allocation of urban space so as to reduce exclusion.

\section{Toward the regulated metropolis}

Lastly, some analyses emphasise the notion of balance at the heart of what is at stake in urban management in China. In-

31. In France, the geographer Guillaume Giroir has devoted a large part of his recent research to the gated communities in the northern suburbs of Beijing.

32. One recalls, for example, recent protests in Shanghai against the projected extension of the Maglev line.

33. In France, one should mention the work of the architect and historian Françoise Ged who has worked on Shanghai.

34. In the context of the global economic crisis that emerged in 2008 , some analysts fear the effects on social stability of an economic growth rate of less than $7 \%$.

35. New studies emphasise the role of the Internet in the forms of protest and in the construction of public debate: it is now being realised that many debates first appear on the Web.

36. Elizabeth J. Perry and Mark Selden (eds.), Chinese Society: Change, Conflict and Resistance, London, Routledge, 2003. 
clining neither towards the linear vision of the hypermodern metropolis, nor towards the constant fragmentation of the contested metropolis, the regulated metropolis approach sets out the necessary investigation of the most suitable and most effective pathways of urban management. The context of rapid urban growth, producing many problems that are sometimes difficult to manage, makes it necessary to weigh choices, and leads, in the "post-Maoist city," to more complex decision-making processes in which institutional players have a decisive role to play, in particular by opening up to other, less visible players. The role of the public authorities, the means of expression of civil society, and the influence of international expertise lie at the heart of this analysis. The phenomena observed in connection with the solution of urban problems show that transition takes place by means of progress achieved through negotiation.

\section{Megalopolitan growth and institutional territories}

The Chinese metropolises are constantly expanding and extending their boundaries. Urban sprawl is tied to the gradual advance of urbanisation on the edges of the city: examination of the satellite images of the major Chinese cities at different dates makes it easy to perceive the growth of the urban footprint since the 1980s. On the one hand, this phenomenon is linked to the dynamics of construction on the peripheries, essentially since 1992, and to the major urban developments launched by China's local authorities. These new developments, often on the edge of economic and technology development zones (ETDZ), are what are commonly called new towns. There is not a single metropolis or provincial capital today without its plans for new towns. The manner of their design baffles European urbanists, to whom the idea of new towns belongs to the past. Their role in China is on a par with what is at stake in the restructuring of the peripheries. Often, their design comes down to projects on an enormous scale: a single city with several million residents, designed by a single architect.

An edifying example is the layout of the new town of Zhengzhou in the province of Henan, attributed to the Japanese architectural practice of Kisho Kurokawa. The city is to have 1.5 million residents. Although the project is considered sensitive by the central government, the province's governor has carried the project through as part of his prerogatives. The same scenario can be found in Inner Mongolia, with the heavily publicised planning of the new town at Ordos. ${ }^{(37)}$ Already, at the beginning of the century, senior
Chinese officials were announcing the design of 400 new cities by 2030. The multiplication of such urban and architectural projects satisfies both a determination to meet the needs of a rapidly growing urban population and the growing pressures of property development, and even speculation. ${ }^{(38)}$

Moreover, urban expansion leads to an extension of the administrative areas of the cities, which come to encompass spaces that are sometimes completely rural. From an administrative point of view, the "urban villages" certainly constitute one of the major specificities of today's urban China; they are particularly studied around Guangdong and in South China. These are village centres that have been integrated into the territory of an urban district (chengqu); once integrated, these villages remain the property of the villagers themselves, according to Chinese landownership law. ${ }^{(39)}$ Well organised, the villagers seek to maximise their capital by increasing the returns on their real estate holdings. This strategy leads to the very high density of construction that is their particularity.

Beyond the impact of the adjustment of the administrative areas of the cities on property development strategies, one must recognise that metropolisation requires taking into account the effects of urban growth at a regional level. The organisation of transport networks, especially the rapidly expanding high-speed train networks, and the localisation of major transport infrastructure, such as airports and stations, confirm the regional dimension of metropolitan organisation. Thus one sees the emergence of immense regional urban agglomerations combining several urban units, especially on the coast where most urbanisation is concentrated ${ }^{(4)}$ : Beijing-Tianjin, the Yangtze delta, the Pearl River delta. ${ }^{(4)} \mathrm{Ac}$ cording to a recent study, urban mega-regions are being constituted in China that concentrate both population and wealth: Shan-King (Shanghai to Nanjing) with 66 million inhabitants and \$130 trillion, Hong-Zhen (Hong Kong and Shenzhen as well as a major part of the Pearl River delta),

37. The ambitious and controversial Ordos project calls for building a model city in the desert of Inner Mongolia. This project, which brings together 100 renowned international architects under the direction of the major landowner Cai Jiang, the Chinese architect Ai Weiwei, and the Swiss firm Herzog et de Meuron, is aimed at giving rise to an ideal city.

38. Speculative pressure is so strong that sometimes these new city areas remain totally uninhabited, thus becoming ghost towns.

39. Under Chinese law, rural land is owned by the village collective.

40. As early as the 1990s, the French geographer Guillaume Giroir envisaged the emergence of an immense megalopolis all along the Chinese coast: "Vers la formation d'une mégalopole côtière," Courrier des pays de l'Est, n418, 1997.

41. In France, the geographer Thierry Sanjuan identified the emergence of a megalopolis in South China very early on. 
the almost unmanageable character of these new megalopolises, characterised not only by urban sprawl and consolidating regional effects, but also by rapid growth in energy consumption and in various forms of pollution. This is all the more so as the studies produced by major international institutions and NGOs constantly emphasise the growing environmental impact of development in China, particularly that of the cities. ${ }^{(49)}$

Some research highlights the limitations of this development model, using the currently fashionable indicator of the ecological footprint: research carried out in Guangdong, for example, shows that the ecological footprint of the city was 2.5 hectares per resident, whereas the load capacity was only 0.2 hectare per resident. This calculation shows that the city, in its development, uses more resources than it possesses. ${ }^{(50)}$ Some approaches focus on more precise questions, such as highlighting the increasing cost of urban mobility through growing reliance on the automobile. Over 20 years, most Chinese metropolises have been transformed from bicycle cities to car cities. ${ }^{\left({ }^{(1)}\right)}$ In the 1980s, the reform of the bicycle industry initiated a massive bicycle craze that led in the 1990s to unusually high rates of household bicycle ownership, often two per family. Bicycle use went hand-in-hand with the first stages of metropolisation, when the suburbs were being developed on the edges of the big cities. The scale of bicycle use incited local authorities to provide suitable facilities: bicycle lanes, parking areas, dedicated traffic lights, etc. In the early 1990s, the big Chinese cities were real bicycle cities. This highly particular situation in worldwide terms was disrupted by the emergence of the automobile in the second half of the 1990s. Under pressure from the automobile industry and from urban sprawl, urban mobility gradually became motorised. After a stage of collective automobile access with taxis, a new stage began at the end of the 1990s with access to the private automobile, the growth of which is now extremely rapid. "Automobile civilisation" (qiche wenming), the appearance of which some in China began to see in the early 1990s, has rapidly become a reality, sparking considerable debate, including on its energy and environmental costs. ${ }^{(22)}$

An increasing number of studies seeking to give greater importance to urban environmental management provide more information about the environmental dimension of metropolisation in China. The latter now has an institutional framework, in particular since the State Environmental Protection Agency (SEPA) was promoted to ministerial level in the spring of 2008, with the aim of taking the environment into greater account in decisions about territorial development. However, while there have been regulations since 1972 in favour of urban environmental protection, major gaps remain in their ap- plication; in particular, procedures are not sufficiently detailed to be really effective. ${ }^{(53)}$ Nevertheless, some local authorities are now seeking to increase their efforts in the environmental field, and are recognised by environmental protection awards from the Chinese government. ${ }^{(54)}$ These efforts are also praised on the international level, with UN Habitat awarding prizes to three cities in the province of Jiangsu ${ }^{(5)}$ for their success in urban management on the occasion of the Nanjing World Urban Forum in November 2008. ${ }^{(56)}$

The particular attention paid to the possibilities of sustainable urban development highlights the technological and organisational innovations that are reportedly being developed more quickly in China than elsewhere. For example Chinese researchers maintain that China has the means to emerge as a pioneer in the "circular economy": waste is treated not only at the end of the cycle, but all along the process of production of goods and in consumption and usage practices. The advantage lies in a considerable reduction in the cost of waste collection and treatment ${ }^{(57)}$; above all, it is more generally a matter of putting into widespread use a new economic approach to environmental issues. This innovation dynamic is now penetrating most urbanisation projects in China based around innovations whose principles often derive from exchange of expertise with Western countries. The most popular and well-known is the Dongtan project for an ecological city on the island of Chongming in the north of the municipality of Shanghai, conceived by the British design firm ARUP. ${ }^{(58)}$ While some see this kind of project as essentially part of an advertising and promotion campaign, to others it

49. The World Health Organisation (WHO) considers Chinese cities to be the most polluted in the world.

50. Guo Xiurui et al., "An Urban Ecological Footprint Approach for Assessing the Urban Sustainability of Guangzhou City, China," Environmental Informatics Archives, vol. 3, 2005, pp. 449-455.

51. Jean-François Doulet and Mathieu Flonneau, Paris-Pékin, civiliser l'automobile, Paris, Descartes et Cie, 2003.

52. See the work of the French economist Julien Allaire

53. Ju Meiting, Shi Lingling, and Chen Xiaohua, "Trends in Chinese Urban Environment Management," Journal of Environmental Assessment Policy and Management, vol. 7, n¹, 2005, pp. 99-124.

54. Between 1997 and 2007,72 cities were entered into the national list of model cities in matters of environmental protection (source: Chinese Ministry for Environmental Protection).

55. These are Nanjing, Shaoxing, and Zhangjiagang.

56. These cities are also inscribed on the national list of model cities in matters of environmental protection: Zhangjiagang since 1997, Shaoxing since 2002, and Nanjing since 2003 (source: Chinese Ministry for Environmental Protection).

57. Let us remember nevertheless that a major part of household waste is recycled by mingong

58. This example expresses only some of the activism in China around sustainable urban development, which tends to produce a dissemination of best practice among Chinese cities. The cities of Dalian and of Tianjin in the north are often considered good case studies. 
seems obvious that China will participate in the emergence of new principles of sustainable urbanisation.

\section{Some perspectives on urban governance}

Analyses of the regulated city situate the stakes of Chinese urban development in a world perspective: the Chinese metropolises, like others all over the world, are seeking an identity as much as they are seeking the most appropriate forms of regulation in order to reduce negative externalities in environmental matters. These explorations lie at the heart of reflection on the establishment of a decision-making mechanism that is more flexible and more open to the now hackneyed notion of "urban governance." Some studies seek to understand the formation of modalities of urban management that are more complex and more representative of the plurality of players. ${ }^{(59)}$

One of the current debates in urban China is the question of representativity: who makes today's city, and for whom? Some see local governments and the property developers as the main players in the city, and as being those who benefit most from it, while the population remains totally excluded from the decision-making process. And yet the question of citizen representation and of the establishment of a mode of urban development based on the demands of urbanites lies at the heart of the political promises of a "harmonious society" broadcast by the Chinese government. More precisely, there is an accepted concept in the field of experts on the city in China, that of "urbanisation for people" (renben chengshi guihua), which maintains that the city must be conceived according to the real needs of its residents, and to some extent, with the residents themselves. The June 2008 catastrophe in Sichuan helped considerably to put this principle back on the agenda. There was a general feeling that if the urbanites had been informed and consulted, the effects of the earthquake might have been reduced. Thus the city of Wenchuan, which was destroyed, now appears to be a testing ground for new practices in urbanisation and urban governance. Moreover, the State Council document on "regulations for reconstruction after the disaster in Wenchuan on 6 June 2008" demands that new urbanisation plans be systematically subject to public enquiry before their approval. ${ }^{\left({ }^{(6)}\right)}$ It seems that new forms of urban governance that are being established in China provide both an adaptation of management modes to the changes linked to the reforms and a State strategy to rely on local organisations in order to maintain its power by favouring decentralisation and the emergence of local institutions. ${ }^{\left({ }^{(1)}\right.}$
In the end, the result is certainly a more complex mechanism that is more receptive to what is at stake in urban management and more aware of the process of concertation. The regulated metropolis approach thus points to the emergence of new norms, new references, and new markers to support what some perceive as a new city project. Urban futures may depend on the establishment of a "Chinese-style" mode of urban governance that would be responsible for selected forms of regulation.

\section{Conclusion - in search of the "new Chinese city"?}

The rapidity of urban transformation in China makes any attempt at interpretation difficult, and raises the question of the identity of today's Chinese metropolis. Should this metropolis still be understood in terms of the significant years of Maoism as the "post-Maoist city," or should it be measured according to its own new and unique characteristics, those of a "new Chinese city"? ${ }^{\left({ }^{(2)}\right)}$ Are not Chinese cities still "emerging cities"? ${ }^{(63)}$ Can one already identify a Chinese urban model? If so, is this a virtuous urban model, as the World Bank tends to maintain? While it does not seem easy or useful to give a definitive verdict, it is salutary to compare the possible approaches to the Chinese metropolis and to explore the complexity of urban phenomena.

A number of events, such as the spotlighting of Beijing on the occasion of the 2008 Olympics, show that the Chinese metropolis has "emerged into the world," becoming more familiar and closer, and to some extent its evolution is being built on new forms of interdependence with the rest of the world. The odds are that the possibilities of Chinese urban development will continue to depend on comparative thinking and stimulating questions, such as those suggested by the 2010 World's Fair being organised in Shanghai, on the theme of the quality of life in the city.

\section{- Translated by Michael Black}

59. One recalls in particular the work in the United States of the urban studies scholar Zhang Tingwei.

60. The municipality of Beijing had already introduced the principle of concertation with the public during the elaboration of its overall plan in 2001.

61. Wu Fulong, "China's Changing Urban Governance in the Transition Towards A More Market-oriented Economy," Urban Studies, vol.39, n, 2002, pp.1071-1093.

62. John Logan (ed.), The New Chinese City, Oxford, Blackwell Publishers, 2001.

63. Wu Fulong (ed.), China's Emerging Cities: The Making of New Urbanism, London, Routledge, 2007 